University of Nebraska - Lincoln

DigitalCommons@University of Nebraska - Lincoln

USDA National Wildlife Research Center - Staff Publications
U.S. Department of Agriculture: Animal and Plant Health Inspection Service

2015

\title{
Chemical repellents appear non-useful for eliciting exit of brown tree snakes from cargo
}

\author{
Fred Kraus \\ Mississippi State University, fkraus@umich.edu \\ Randal S. Stahl \\ USDA-APHIS-Wildlife Services, randal.s.stahl@aphis.usda.gov \\ William Pitt \\ U.S. Department of Agriculture, Animal Plant Health Inspection Service, Wildlife Services, National Wildlife \\ Research Center, Hilo, HI
}

Follow this and additional works at: https://digitalcommons.unl.edu/icwdm_usdanwrc

Part of the Life Sciences Commons

Kraus, Fred; Stahl, Randal S.; and Pitt, William, "Chemical repellents appear non-useful for eliciting exit of brown tree snakes from cargo" (2015). USDA National Wildlife Research Center - Staff Publications. 1702. https://digitalcommons.unl.edu/icwdm_usdanwrc/1702

This Article is brought to you for free and open access by the U.S. Department of Agriculture: Animal and Plant Health Inspection Service at DigitalCommons@University of Nebraska - Lincoln. It has been accepted for inclusion in USDA National Wildlife Research Center - Staff Publications by an authorized administrator of DigitalCommons@University of Nebraska - Lincoln. 


\title{
Chemical repellents appear non-useful for eliciting exit of brown tree snakes from cargo
}

\author{
Fred Kraus $^{\mathrm{a}, 1 *}$, Randal Stahl ${ }^{\mathrm{b}}$ and William Pitt ${ }^{\mathrm{c}, 2}$ \\ ${ }^{a}$ Department of Wildlife, Fisheries \& Aquaculture, Mississippi State University, Mississippi State, MS, USA, ${ }^{b}$ U.S. Department of \\ Agriculture, Animal Plant Health Inspection Service, Wildlife Services, National Wildlife Research Center, Fort Collins, CO, USA; ${ }^{c}$ U.S. \\ Department of Agriculture, Animal Plant Health Inspection Service, Wildlife Services, National Wildlife Research Center, Hilo, HI, USA
}

(Received 5 November 2014; final version received 23 February 2015)

\begin{abstract}
The brown tree snake (Boiga irregularis) is invasive in Guam, has imposed ecological and economic problems there, and threatens to be dispersed via cargo and vehicles to other islands in the Pacific, where it could be expected to inflict similar damages. Prevention of inadvertent snake export currently relies on cargo inspection and suppression of snake populations around ports, which are expensive and incompletely reliable. Hence, there has long been interest in developing additional tools to preclude snakes leaving in cargo, and fumigation with essential oils has been suggested for this role. We tested gaseous or aerosol deliveries of several essential oils and three other candidate irritants. We found none to work reliably in repelling snakes, and we discuss several limitations that make development of an effective fumigation tool from these chemicals improbable. Additional effort to develop an operational tool using essential oils would likely be misdirected, and effective fumigation methods for invasive snakes should be sought elsewhere.
\end{abstract}

Keywords: alien species; Boiga irregularis; brown tree snake; carbon dioxide; essential oils; fumigation; naphthalene

\section{Introduction}

The brown tree snake (Boiga irregularis) is an invasive species introduced to Guam during or soon after World War II, and it continues to exert ecological and economic damage on Guam (Fritts \& Rodda 1998; Rodda \& Savidge 2007). It also poses the threat of establishment on other Pacific islands via accidental off-island transport of snakes hiding in outbound cargo or vehicles (Fritts et al. 1999; Vice \& Vice 2004). Presently, the only means for detecting snakes sequestered in cargo is with dogs trained to detect snakes (Engeman et al. 1998, 2002; Vice et al. 2009). This technology is largely effective but requires highly trained personnel and dogs, and the program is correspondingly expensive. Additional cost-effective tools for ensuring the absence of snakes in cargo departing Guam would therefore be of great benefit. Furthermore, not all cargo leaving Guam receives canine inspection prior to export (Engeman \& Vice 2002); therefore, having a quick, cheap, and reliable method to treat previously uninspected Guam-derived cargo in recipient ports would provide those jurisdictions additional protection. To meet these goals, chemical fumigants have long been suggested as a potential solution to elicit exit of brown tree snakes from cargo refuges (Brown Tree Snake Control Committee 1996; Clark \& Shivik 2002; Engeman \& Vice 2002), and they continue to receive interest at meetings of the Brown Tree Snake Working Group, but they have remained untested. Such technology would require minimal training for effective application, and some chemicals - in particular, essential oils and their constituent active ingredients - have been found to elicit strong aversive responses when sprayed directly onto brown tree snakes (Clark \& Shivik 2002). These chemicals in particular have long been thought to hold promise as a management tool. Certain solvents and petroleum distillates have also been shown to be effective repellents or irritants for brown tree snakes (T. Mathies \& W. Pitt unpublished data) or other snakes (Nishimura 1999), but their use could prove logistically problematic.

Military activities account for a large proportion of the export risk for brown tree snakes because of the large military presence on Guam. Department of Defense activities on Guam have accounted for a substantial fraction of snakes accidentally exported from Guam (Fritts 1987; Fritts et al. 1999), and activities are scheduled to increase substantially over the next several years with planned military expansion there (Robertson 2011). Consequently, the number and scope of training exercises requiring transport of military personnel and cargo from Guam to other islands in the Pacific will step up greatly, increasing the risk of off-island transport and establishment of brown tree snakes. Thus, the military has a particularly acute need for a repellent-and-delivery system able to elicit timely exit of snakes from cargo.

Despite early results suggesting that essential oils might find use as effective snake repellents (Clark \& Shivik 2002), several potential limitations must be overcome for chemical fumigation to be an effective means of

\footnotetext{
*Corresponding author. Email: fkraus@umich.edu

${ }^{1}$ Present address: Department of Ecology and Evolutionary Biology, University of Michigan, Ann Arbor, MI 48109, USA.

${ }^{2}$ Present address: Smithsonian Conservation Biology Institute, National Zoological Park, 1500 Remount Road, Front Royal, VA 22630, USA.
} 
impelling snakes to exit cargo. First, any such chemical must be able to penetrate and attain a high enough concentration in all potential cargo refuges to drive out snakes. Effective penetration may be a problem for chemical fogs, which cannot diffuse through packed cargo. Production of a molecular vapor (a gas), as opposed to an aerosol, could avoid this problem, but several of the chemicals demonstrated to elicit strong reactions from snakes have low vapor pressures and may not be readily volatilized. Further, the Air Force and Marines make wide use of the 463L Master Pallet to transport material in inter-island training exercises. Such palletized cargo presents an additional challenge to the efficacy of any repellent tool because, unlike shipping containers, loaded pallets do not provide a "closed space" that more easily enables vapors of an agent to reach high enough concentrations to confer repellency. Close packing of cargo could also prevent access to all internal air spaces. Second, an effective chemical must be unreactive so as to avoid damaging exposed cargo goods. Chemicals that, to date, have been shown to have irritant qualities on snakes include several essential oils (Clark \& Shivik 2002), solvents, and petroleum distillates (Nishimura 1999; T. Mathies \& W. Pitt unpublished data). Several of these may be undesirably reactive. Third, the chemical must be effective as a snake irritant at a concentration that is safe for human use. Several of the essential oils have significant physiological responses in mammals, insects, or microbiota. For example, grapefruit oil has been shown to impact plasma cortisol and prolactin levels in Holstein steers (Sutoh et al. 2013) and to interfere with morphological development stages in the yellow-fever mosquito, Aedes aegypti (Ivoke et al. 2013). Citronellal, a major component in citronella oil, influences the behavior of mice to mechanical pain reception (de Santana et al. 2013) and also has uses as a repellent for $A$. aegypti (Hsu et al. 2013). The lavender oil, Linalool, has been demonstrated to be a sedative for mice following inhalation (Linck et al. 2009). Some of the solvents established as snake irritants (e.g., chloroform, trichloroethylene, T. Mathies \& W. Pitt unpublished data) are human anesthetics, necessitating the use of specialized personal protective equipment by human applicators, if used, particularly in confined spaces such as warehouses. Thus, it is important that titers of candidate chemicals be safe for human use when applied at an operational scale.

The overall aim of this study was to evaluate efficacies of several chemical agents to elicit exit of brown tree snakes from simulated refuges using mechanically forced movement of molecular vapors and aerosols. To meet this goal, we investigated some of the essential oils identified by Clark and Shivik (2002) as eliciting strong aversive reactions in brown tree snakes, as well as three additional candidate irritants. We assessed feasibility both with respect to (1) the ability of the chemical to elicit an aversive reaction from the snakes, and (2) whether the amount of chemical needed to elicit exit, its reactivity, and its hazard to humans can meet realistic operational needs. The end goal of this research is to develop a snake repellent and delivery system for use on palletized and containerized cargo that can be used to impel the exit of snakes from cargo in a relatively rapid period of time ( $\leq 5$ minutes). The need for rapid exit is imposed by the practical need for processing cargo quickly given the large amounts transiting Guam and the need to minimize interference with shipping operations.

\section{Materials and methods}

\subsection{Test site and animals}

Testing was conducted in March 2013 at USDA's National Wildlife Research Center (NWRC) in Fort Collins inside a heated, humidified environmental room that simulates the prevailing environmental conditions on Guam $\left(32^{\circ} \mathrm{C}, 80 \%\right.$ humidity, 12:12 light/dark cycle). Snakes used in the trials were all large captive adults maintained since May 2007 in $23 \mathrm{~cm} \times 40 \mathrm{~cm} \times 61 \mathrm{~cm}$ cages at NWRC under the same environmental conditions as used during the tests; a subsample of specimens (taken so as not to stress every animal) varied from $513-1065 \mathrm{~g}$ in mass and $126-178 \mathrm{~cm}$ in snout-vent length. These test subjects were larger than the average snake seen in cargo situations on Guam. Each snake was transferred to the test refuge (see Test apparatus section below) for at least one hour prior to testing so as to allow the snake to settle following the transfer procedure. All animal use was conducted with the approval of NWRC's animal care and use committee.

\subsection{Test apparatus}

Snakes were tested inside an experimental refuge consisting of a commercially available translucent polyethylene container measuring $17 \mathrm{~cm} \times 33 \mathrm{~cm} \times 42 \mathrm{~cm}$ and having a volume of $14.2 \mathrm{~L}$. A 7.5-cm-diameter hole was drilled at one end of the container and covered with hardware cloth. During experimental trials, this hole was placed next to the end of a 69-cm-long inlet pipe from which were introduced the molecular vapors or aerosols of the test chemicals (Figure 1). On the side of the refuge container near the opposite end was drilled a second 7.5-cm-diameter exit hole that abutted flush onto an aluminum exit pipe faced with glass and having dimensions $7 \mathrm{~cm} \times 10 \mathrm{~cm} \times$ $152 \mathrm{~cm}$ and a volume of $10.4 \mathrm{~L}$. This hole was covered with duct tape to prevent escape while the snake was acclimating to the container, and the tape was removed as the container was inserted into the test apparatus. The length of the exit pipe is more than half the length of the longest dimension of a 463L Master Pallet $(274 \mathrm{~cm} \times$ $224 \mathrm{~cm}$; height restrictions vary among aircraft types); successful exit of this length of pipe would signal likely the exit of containers and pallets under operational conditions, even for snakes sequestered in the center of cargo containers. Air volume of the refuge, entry pipe, and exit tube summed to $31 \mathrm{~L}$. The refuge, exit pipe, and approximately half of the input pipe were then fixed in a wooden box $(20 \mathrm{~cm} \times 66 \mathrm{~cm} \times 169 \mathrm{~cm})$ with hinged lids to allow the experiments to be conducted in darkness (Figure 1). By housing the refuge containing a snake and its potential 


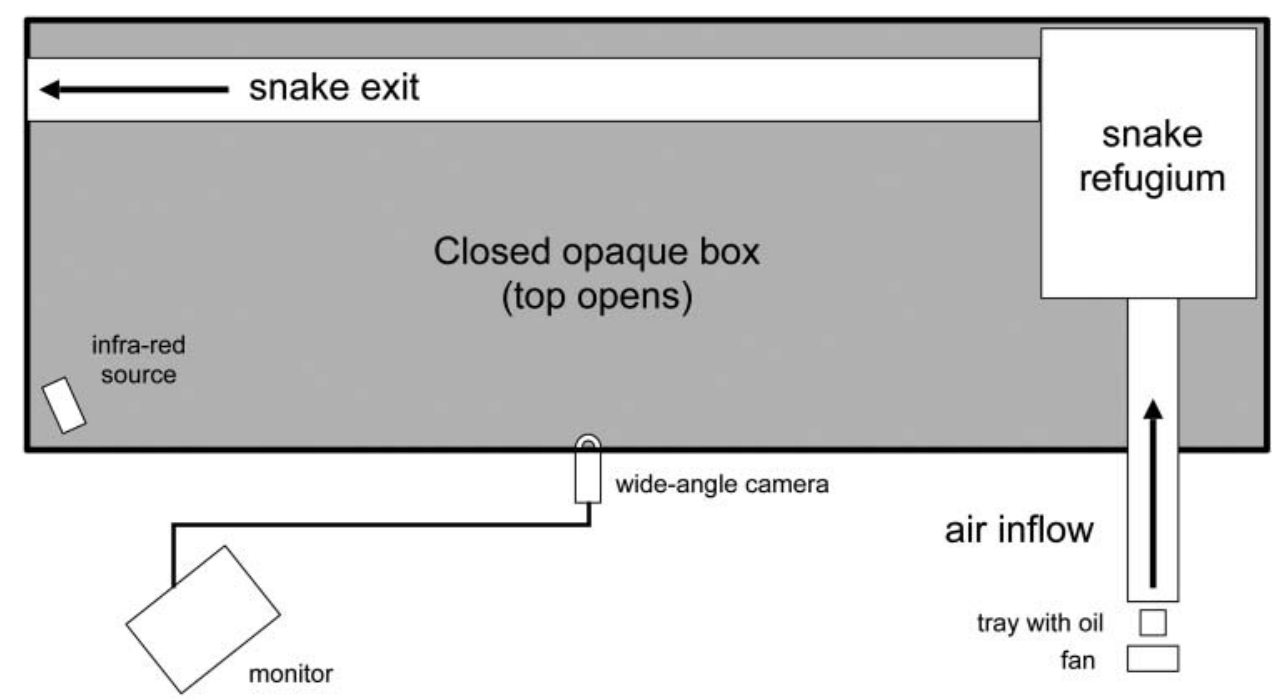

Figure 1. Diagram of the test apparatus showing connections between snake refuge, inlet pipe, and exit pipe, and the placement of the wide-angle camera and infrared source within the opaque test container.

escape route in a darkened box simulating real cargo, a realistic challenge to exit is presented. Because brown tree snakes are nocturnal, a snake inside the apparatus would be expected to reluctantly exit the darkened pipe to enter into a well-lit room. Thus, as under field conditions, a snake will have to choose between opposing adverse stimuli: light vs. irritant. The top of the wooden box consisted of three hinged panels that could be raised to allow for rapid exchange of refuges and cleaning of the inlet and exit pipes. A small hole was drilled into the front of the enclosing wooden box into which was fitted an infrared camera connected to a video monitor that allowed activities of the test subjects to be monitored; a small infrared lamp was placed in the corner of the box to provide illumination (Figure 1). This camera allowed for observation of all snake activities; the view extended from the refuge to the exit at the far end of the test apparatus.

\subsection{Test procedure}

At the start of each test, one of the 14-L refuges in which a snake had been acclimated for at least one hour was introduced into the enclosing apparatus, the inlet pipe placed flush with the side of the refuge at the entry opening, and the hinged top of the box closed. Chemical compounds were introduced into the refuge in one of the two ways. First, essential oils, chloroform, or naphthalene was placed into a weigh boat at the entrance of the inlet tube and molecular vapors were generated with a small fan slowly blowing air over the compound and into the inlet tube toward the refuge; trials varied in whether the compound was heated from below with a heating pad or left to evaporate using only the fan at an ambient temperature $\left(32{ }^{\circ} \mathrm{C}\right)$. Further, we varied fan speed to see if volatilization was improved with higher speeds; we measured airflow with a Kestrel wind meter. Second, aerosolized essential oils were generated at the entrance of the inlet tube using a Model Maker model SA200P airbrush atomizer, and this aerosol was blown down the inlet tube using the same small fan so as to produce a fine mist. Oil solutions varied from $1 \%$ to $100 \%$ of commercial essential oils (source: Bulk Apothecary); dilutions were made in methanol. Dilutions were tested because the high viscosity of the oils impeded both vaporization and formation of aerosols. Oils tested were anise, cedar wood, cinnamon, citronella, clary sage, grapefruit, lavender, and rosemary oils. Chloroform was included because it is known to elicit exit of snakes from test refuges when applied as a chemical fog (T. Mathies \& W. Pitt unpublished data). Entry and exit tubes were cleaned with isopropanol between trials. After each trial, snakes were removed from test refuges and the refuge cleaned with isopropanol prior to further use.

Third, naphthalene was tested by placing crystals into a weigh boat and gently blowing the generated vapors down the tube with a small fan. As for trials using essential oils, treatments varied in whether the crystals were vaporized only with the stream of air from the fan or by also applying heat from below with a heating pad.

Lastly, carbon dioxide was tested by venting a stream from a commercial tank into the beginning of the inlet tube and blowing it toward the refuge with a small fan. This produced streams of air varying from $1 \%$ to $6.3 \%$ $\mathrm{CO}_{2}$. In a single trial, $\mathrm{CO}_{2}$ was vented from the tank directly into the refuge entrance instead of into the entrance of the entry tube. We tested carbon dioxide because it is well known as a vertebrate mucosal irritant at modest concentrations.

Preliminary trials of essential oils used an arbitrarily selected set of snakes that were equally distributed by sex (17 trials with 13 males, 17 trials with 5 females); $\mathrm{CO}_{2}$ trials used only males. Snakes were only used for multiple trials if initial trials led to no response. All trials were terminated either when a snake exited the apparatus or at five minutes, with test subjects removed from the apparatus at that time. 


\subsection{Data}

With a stopwatch we recorded to the nearest second times to (1) the first snake movement, and (2) the exit of snake from the exit tube. Quantities of chemicals utilized were determined by measuring the mass of the weigh boat + chemical before and after the trials with an Ohaus portable pan balance and determining the difference between the two measurements. Data on tested chemicals were retrieved from their material safety data (MSD) sheets.

\section{Results}

\subsection{Essential oils}

Molecular vapor trials with essential oils involved five females and two males and elicited no response from snakes (Table 1). In most trials, no measurable evaporation occurred, even though the vapors were readily detectable to the human nose. However, the $10 \%$ solution of citronella oil generated a measurable amount of volatilization, although that too was of insufficient quantity to elicit a reaction from the test animal.

When aerosolized, essential oils were more effective, with six of the nine subjects (all male) appearing to react to the introduction of the aerosol, but only five exiting the test apparatus (Table 2). Furthermore, quantities needed to obtain a snake response were large $(3.4,5.4,5.5,6.5$, 7.3 , and $7.6 \mathrm{~g}$ ) and the response was variable across tests, even for the same chemical and identical concentrations (Table 2). For example, in one test, $6.5 \mathrm{~g}$ of $10 \%$ citronella oil was sufficient to cause a snake to exit the test apparatus, but in other trials, 8.2 and $8.6 \mathrm{~g}$ of the same compound were insufficient to do so. Responses were of higher frequency when using $30 \%$ concentrations of oil instead of $10 \%$ solutions, with half of the subjects exiting the test apparatus (Table 2).

\subsection{Chloroform}

Molecular vapors of chloroform elicited no response from a single test subject even though this chemical produced the highest rates of conversion to vapor of any of the test materials (Table 1).

\subsection{Naphthalene}

Molecular vapors of naphthalene elicited some movement from two males when crystals were heated, but two females failed to react when the chemical was unheated (Table 1). Snakes slowly shifted position but did not exit the refuge or experimental apparatus, although one snake looped part of its body $32 \mathrm{~cm}$ down the exit tube but retained its head inside the refuge, suggesting no particular effect from the chemical.

\subsection{Carbon dioxide}

When carbon dioxide gas was introduced into the refuge in concentrations varying from $1 \%$ to $6.3 \%$, no effect on the two male subjects was observed, with one exception.

Table 1. Reaction times to molecular vapors of chemicals with potential repellency for brown tree snakes; each row is a single trial. $T_{\text {move }}$ and $T_{\text {exit }}$ are time for snake to first respond to the stimulus and time for snake to exit the test apparatus, respectively. $\Delta$ mass is the amount of the compound used in each trial. Oil dilutions are in methanol. "-" signifies no response.

\begin{tabular}{|c|c|c|c|c|c|c|}
\hline Chemical & Trial time (s) & Heat $\left({ }^{\circ} \mathrm{C}\right)$ & Fan speed $(\mathrm{m} / \mathrm{s})$ & $\Delta$ mass $(\mathrm{g})$ & $T_{\text {move }}(\mathrm{s})$ & $T_{\text {exit }}(\mathrm{s})$ \\
\hline $1 \%$ grapefruit oil & 300 & 70.9 & 0.7 & 0.2 & - & - \\
\hline $1 \%$ grapefruit oil & 300 & 110.7 & 0.7 & 0.3 & - & - \\
\hline $10 \%$ cinnamon oil & 180 & 54 & 7.5 & 1.1 & - & - \\
\hline $10 \%$ cinnamon oil & 180 & 54 & 7.5 & 0 & - & - \\
\hline $10 \%$ citronella oil & 180 & 54 & 7.5 & 3.1 & - & - \\
\hline $100 \%$ anise oil & 180 & 32 & 0.7 & 0 & - & - \\
\hline $100 \%$ anise oil & 180 & 32 & 2.5 & 0 & - & - \\
\hline $100 \%$ cedarwood oil & 180 & 32 & 2.5 & 0 & - & - \\
\hline $100 \%$ cinnamon oil & 180 & 32 & 2.5 & 0 & - & - \\
\hline $100 \%$ citronella oil & 180 & 32 & 2.5 & 0 & - & - \\
\hline $100 \%$ clary sage oil & 180 & 32 & 2.5 & 0 & - & - \\
\hline $100 \%$ grapefruit oil & 180 & 32 & 2.5 & 0 & - & - \\
\hline $100 \%$ juniper oil & 180 & 32 & 2.5 & 0 & - & - \\
\hline $100 \%$ lavender oil & 180 & 32 & 2.5 & 0 & - & - \\
\hline $100 \%$ rosemary oil & 180 & 32 & 2.5 & 0 & - & - \\
\hline Chloroform & 180 & 47.5 & 2.5 & 1.2 & - & - \\
\hline Chloroform & 180 & 70.9 & 2.5 & 5.4 & - & - \\
\hline Chloroform & 300 & 70.9 & 0.7 & 5.5 & - & - \\
\hline Naphthalene & 180 & 32 & 2.5 & 0 & - & - \\
\hline Naphthalene & 180 & 32 & 2.5 & 0 & - & - \\
\hline Naphthalene & 180 & 54 & 7.5 & 0.3 & 108 & - \\
\hline Naphthalene & 180 & 54 & 7.5 & 0 & 54 & - \\
\hline
\end{tabular}


Table 2. Reaction times to aerosolized chemicals with potential repellency for brown tree snakes; each row is a single trial. $T_{\text {move }}$ and $T_{\text {exit }}$ are time for snake to first respond to the stimulus and time for snake to exit the test apparatus, respectively. $\Delta$ mass is the amount of the compound used in each trial. Oil dilutions are in methanol. "-" signifies no response.

\begin{tabular}{|c|c|c|c|c|c|c|}
\hline Chemical & Trial time (s) & Heat $\left({ }^{\circ} \mathrm{C}\right)$ & Fan speed $(\mathrm{m} / \mathrm{s})$ & $\Delta$ mass $(\mathrm{g})$ & $T_{\text {move }}(\mathrm{s})$ & $T_{\text {exit }}(\mathrm{s})$ \\
\hline $1 \%$ grapefruit oil & 150 & 32 & 2.6 & 15.2 & - & - \\
\hline $10 \%$ cinnamon oil & 180 & 32 & 2.5 & 0.9 & - & - \\
\hline $10 \%$ cinnamon oil & 54 & 32 & 2.6 & 5.4 & Not noted & 54 \\
\hline $10 \%$ cinnamon oil & 100 & 32 & 2.6 & 7.6 & 190 & 225 \\
\hline $10 \%$ citronella oil & 56 & 32 & 2.5 & 6.5 & 56 & 64 \\
\hline $10 \%$ citronella oil & 120 & 32 & 2.6 & 8.6 & - & - \\
\hline $10 \%$ citronella oil & 120 & 32 & 2.6 & 8.2 & - & - \\
\hline $10 \%$ rosemary oil & 120 & 32 & 2.6 & 6.6 & - & - \\
\hline $30 \%$ cinnamon oil & 40 & 48 & 4.2 & 3.4 & Not noted & 40 \\
\hline $30 \%$ citronella oil & 130 & 48 & 4.2 & 7.3 & 10 & * \\
\hline $30 \%$ juniper oil & 71 & 48 & 4.2 & 5.5 & 23 & 71 \\
\hline $30 \%$ lavender oil & 95 & 48 & 4.2 & 7.3 & 15 & - \\
\hline
\end{tabular}

${ }^{*}$ Snake progressed to the end of the exit tube but turned back into the test apparatus and failed to exit.

In the single trial in which the gas was vented directly into the entrance of the refuge instead of the beginning of the inlet tube, the subject moved after $90 \mathrm{~s}$ (Table 3). This was likely merely a response to air movement per se inasmuch as the snake exhibited no sign of distress and made no attempt to exit the refuge.

\section{Discussion}

Essential oils have shown the ability to elicit a vigorous avoidance response in brown tree snakes when directly applied on their heads as an aerosol (Clark \& Shivik 2002), and chloroform and trichloroethylene also elicit avoidance in these snakes when a fog is settled on them (T. Mathies \& W. Pitt unpublished data). In a related vein, creosote soap, light oil, heavy oil, xylene, kerosene, and kerosene-based insecticides have shown some degree of repellency for the viper Protobothrops flavoviridis, with xylene and the insecticides being able to expel those snakes from experimental refuges within 10 minutes (Nishimura 1999). Although these results are suggestive that effective chemical repellents could conceivably be developed for snakes, a number of limitations would appear to restrict their efficaciousness under operational conditions. In the present instance, we were concerned to identify chemicals that could be used to elicit exit of snakes from cargo refuges, a need that imposes additional considerations that may not apply to irritant use under other circumstances. Our results suggest that none of these chemicals may easily be converted into a useful operational tool. We review those reasons here.

First, for the compounds we tested, only aerosols proved effective in eliciting avoidance behavior from snakes; direct contact with the liquid state seems required for repellency of essential oils to be effective. We were unable to create a molecular vapor from any essential oil or from naphthalene that was sufficiently dense to elicit snake exit. This is likely because vapor pressures of these compounds are so low (Table 4) that we could not generate concentrated molecular vapors by evaporation with either a low stream of air or the airstream in concert with heat. Increased heating to improve evaporation may also be limited for several of these chemicals by their low flashpoints (Table 4), requiring that care be taken to avoid their inadvertent ignition. Because of the difficulty of creating concentrated molecular vapors of these essential oils, reliance of their use as snake repellents must necessarily involve the use of aerosolized formulations. However, aerosols cannot penetrate the entire airspace of a cargo load because they can only be propelled in a straight

Table 3. Reaction times to carbon dioxide for brown tree snakes; each row is a single trial. All trials were for $180 \mathrm{~s}$. $T_{\text {move }}$ and $T_{\text {exit }}$ are time for snake to first respond to the stimulus and time for snake to exit the test apparatus, respectively. "_" signifies no response.

\begin{tabular}{lcccc}
\hline $\mathrm{CO}_{2}$ released at: & Fan speed $(\mathrm{m} / \mathrm{s})$ & $\mathrm{CO}_{2}$ concentration in airstream & $T_{\text {move }}(\mathrm{s})$ & $T_{\text {exit }}(\mathrm{s})$ \\
\hline Entrance of inlet tube & 0.7 & $1 \%$ & - & - \\
$15 \mathrm{~cm}$ before inlet tube & 0.7 & $1 \%$ & - & - \\
Entrance of inlet tube & 0.7 & $2 \%$ & 90 & - \\
Entrance of refuge & 0 & $2 \%$ & - & - \\
Entrance of inlet tube & 0.7 & $2 \%$ & - & - \\
Entrance of inlet tube & 0.7 & $6.3 \%$ & - \\
Entrance of inlet tube & 0.7 & & - \\
\hline
\end{tabular}


Table 4. Physical properties of tested essential oils relevant to assessing practicality of their use under operational conditions. Chemical data are from Taarit et al. (2011), Teixera et al. (2013), Tumen et al. (2013), Xing et al. (2014), Yoon et al. (2011), Zheljaskov et al. (2013), and www.chemspider.org.

\begin{tabular}{|c|c|c|c|c|c|c|c|c|}
\hline $\begin{array}{l}\text { Essential } \\
\text { oil }\end{array}$ & $\begin{array}{l}\text { Constituent } \\
\text { compound }\end{array}$ & $\begin{array}{l}\text { Percent } \\
\text { by mass }\end{array}$ & $\begin{array}{l}\text { Vapor pressure } \\
\left(\mathrm{mm} \mathrm{Hg} \text { at } 25^{\circ} \mathrm{C}\right)\end{array}$ & $\begin{array}{c}\text { Flash } \\
\text { point }\left({ }^{\circ} \mathrm{C}\right)\end{array}$ & $\log K_{\text {ow }}{ }^{a}$ & Flammability $^{\mathrm{b}}$ & $\begin{array}{l}\text { Health } \\
\text { hazard }^{\mathrm{b}}\end{array}$ & Reactivity $^{c}$ \\
\hline \multirow[t]{2}{*}{ Anise } & & & & 83.3 & & 2 & 2 & $\mathrm{I}, \mathrm{P}$ \\
\hline & Anethole & 92 & 0.0634 & 90.0 & 3.39 & 2 & 2 & NA \\
\hline \multirow[t]{3}{*}{ Cedarwood } & & & & 110 & & 1 & 2 & I \\
\hline & Cedrol & 62 & 0.000124 & 115.5 & 4.33 & NA & NA & NA \\
\hline & Widdrol & 18 & 0.000071 & 128.4 & 4.84 & NA & NA & NA \\
\hline \multirow[t]{2}{*}{ Cinnamon } & & & & 61 & & 2 & 2 & I \\
\hline & Cinnamaldehyde & 85 & 0.0337 & 71 & 1.82 & 2 & 2 & \\
\hline \multirow[t]{5}{*}{ Citronella } & & & & 77 & & 2 & 2 & $\mathrm{H}, \mathrm{I}$ \\
\hline & D3-carene & 22.5 & 2.09 & 46 & 4.61 & NA & NA & NA \\
\hline & $\beta$-citronellal & 9 & 0.254 & 75 & 3.53 & 2 & 1 & NA \\
\hline & (-)-Camphor & 11.9 & 0.017 & 65 & 3.04 & NA & NA & NA \\
\hline & Eremophilene & 9.8 & 0.0331 & 106 & 6.3 & NA & NA & NA \\
\hline \multirow[t]{4}{*}{ Clary sage } & & & & 79.4 & & 2 & 2 & NA \\
\hline & Germacrene-D & 28 & 0.007000 & 111.9 & 4.92 & NA & NA & NA \\
\hline & Manoyle oxide & 12.8 & 0.000187 & & 6.47 & NA & NA & NA \\
\hline & Phytol & 12.8 & 0.000003 & 110 & 8.32 & NA & NA & NA \\
\hline \multirow[t]{2}{*}{ Grapefruit } & & & & 45 & & 1 & 2 & I \\
\hline & $\alpha$-limonene & 85 & 1.45 & 46 & 4.83 & 2 & 1 & NA \\
\hline \multirow[t]{3}{*}{ Juniper } & & & & 41 & & 1 & 1 & NA \\
\hline & $\alpha$-pinene & 7.2 & 4.02 & 33 & 4.27 & 3 & 1 & NA \\
\hline & Sabinene & 54 & 7.36 & 36.7 & 4.69 & NA & NA & NA \\
\hline \multirow[t]{3}{*}{ Lavender } & & & & 71.1 & & 2 & 1 & NA \\
\hline & Linalool & 42.2 & 0.0832 & 76 & 3.38 & NA & NA & NA \\
\hline & Linalyl acetate & 49.9 & 0.131 & 69.6 & 4.39 & NA & NA & NA \\
\hline \multirow[t]{4}{*}{ Rosemary } & & & & 40 & & 1 & 2 & I \\
\hline & (-)-Camphor & 35.5 & 0.017 & 65 & 3.04 & NA & NA & NA \\
\hline & Eucalyptol & 18.2 & 1.56 & 49 & 3.13 & NA & NA & NA \\
\hline & (-)-Bornyl acetate & 13.4 & 0.107 & 84 & 3.86 & NA & NA & NA \\
\hline
\end{tabular}

${ }^{a}$ logConcentration in octanol phase/concentration in aqueous phase. From EPISuite prediction.

${ }^{\mathrm{b}}$ Ratings from National Fire Protection Association. NA = information unavailable.

${ }^{\mathrm{c}}$ From material safety data sheets. $\mathrm{H}=$ high skin-contact hazard, $\mathrm{I}=$ inhalation irritant, $\mathrm{P}=$ polymerizable. $\mathrm{NA}=$ information unavailable.

stream from the source and cannot readily diffuse through the convoluted passageways that characterize packed cargo. Consequently, not all spaces in a cargo load are susceptible to exposure to aerosols, severely limiting their ability to elicit exit of stowaway snakes.

Second, we found even aerosolized formulations of essential oils did not produce consistent escape results (Table 2). Sample sizes in our trials are admittedly small, but results were so poor and contrary to operational needs that we viewed additional trials as pointless. Similar problems were met with other, more volatile, chemicals tested for snake repellency (Nishimura 1999, T. Mathies \&
W. Pitt unpublished data). Droplet size may be a major controlling factor for snake response to aerosols.

Third, even if aerosolized essential oils could turn corners and were efficacious in eliciting snake escape behavior, their use in cargo operations would leave a persistent residue on the contained goods. Several of the constituent compounds in essential oils are aldehydes and are potentially reactive. For example, the major cinnamon-oil constituent cinnamaldehyde is a moderate sensitizer (Williams et al. 2015) and is capable of degrading other organic compounds (Xing et al 2014). Therefore, certain goods (e.g., electronics, plastics) would be susceptible to 
Table 5. Amounts of aerosolized essential oils required to treat the extremes of standard cargo pallet/container sizes using the values found effective in this study to elicit exit of brown tree snakes from test refuges (Table 2). GMA wooden pallet has a base area of 102 $\mathrm{cm} \times 122 \mathrm{~cm}$ and is assumed to be stacked to a height of $102 \mathrm{~cm}=1.26 \mathrm{~m}^{3} ; 463-\mathrm{L}$ pallet has a base area of $213 \mathrm{~cm} \times 264 \mathrm{~cm}$ and is assumed to be stacked to a height of $213 \mathrm{~cm}=12 \mathrm{~m}^{3}$. Amounts of oils needed for treatment vary depending of amounts of airspace assumed to remain in the pallets.

\begin{tabular}{|c|c|c|c|c|c|c|c|c|c|c|}
\hline \multirow[b]{2}{*}{ Oil } & \multirow{2}{*}{$\begin{array}{l}\text { Amount } \\
\text { used (g) }\end{array}$} & \multicolumn{4}{|c|}{$\begin{array}{c}\text { Amount }(\mathrm{g}) \text { needed for GMA } \\
\text { wooden pallet assuming airspace of: }\end{array}$} & \multicolumn{4}{|c|}{$\begin{array}{l}\text { Amount }(\mathrm{g}) \text { needed for } 463-\mathrm{L} \\
\text { military pallet assuming airspace of: }\end{array}$} & \multirow{2}{*}{$\begin{array}{l}\text { Dermal toxicity for } \\
75 \mathrm{~kg} \text { human }(\mathrm{g})\end{array}$} \\
\hline & & $1 \%$ & $5 \%$ & $10 \%$ & $20 \%$ & $1 \%$ & $5 \%$ & $10 \%$ & $20 \%$ & \\
\hline $30 \%$ juniper & 5.5 & 0.67 & 3.35 & 6.70 & 13.41 & 6.38 & 31.92 & 63.84 & 127.68 & unknown \\
\hline $10 \%$ citronella & 6.5 & 0.26 & 1.32 & 2.65 & 5.29 & 2.52 & 12.60 & 25.20 & 50.40 & 352 \\
\hline $30 \%$ citronella & 7.3 & 0.89 & 4.45 & 8.90 & 17.79 & 8.47 & 42.36 & 84.72 & 169.44 & 352 \\
\hline $10 \%$ cinnamon & 5.4 & 0.22 & 1.10 & 2.19 & 4.38 & 2.09 & 10.44 & 20.88 & 41.76 & 24 \\
\hline $10 \%$ cinnamon & 7.6 & 0.31 & 1.54 & 3.09 & 6.17 & 2.94 & 14.70 & 29.40 & 58.80 & 24 \\
\hline $30 \%$ cinnamon & 3.4 & 0.41 & 2.07 & 4.14 & 8.29 & 3.95 & 19.74 & 39.48 & 78.96 & 24 \\
\hline
\end{tabular}

damage from at least some of these oils. This same concern applies to other, more volatile, chemicals tested for snake repellency (Nishimura 1999; T. Mathies \& W. Pitt unpublished data). This problem precludes the use of these chemicals for sensitive cargo, requiring development of additional methods in those circumstances, but it would be desirable to have a fumigation method applicable to all cargo types. Further, even when chemically unreactive, a persistent odor would cling to all cargos (and warehouse environs) treated with essential oils. This would undoubtedly be considered undesirable by commercial interests and probably by warehouse personnel as well.

Last, the quantities of aerosolized essential oils needed for application to a container or pallet of cargo are sufficiently large that it could pose a potential health threat to unprotected applicators and adjacent personnel. Toxic quantities of some of these chemicals are rather low (Table 5) and most are readily transported across membranes, as indicated by their high $\log K_{\text {ow }}$ values (Table 4 ), which measures the partition of a compound between two immiscible liquids and favors the compounds partitioning to a more hydrophobic phase. And although we do not argue that exposure in those quantities is likely to be achieved during regular operations or likely to be lethal, we note that even the miniscule amounts of chemicals to which two of the authors were exposed during these trials were quite irritating. But these trials used much less compound than would be needed under operational situations treating much larger volumes (Table 5) and numbers of containers. Given these issues, the use of protective gear such as Hazmat suits could be required to ensure safe application of product. We do not think such a requirement would be viewed as acceptable under the prevailing heat $\left(26-32{ }^{\circ} \mathrm{C}\right)$ and humidity $(80 \%-100 \%)$ conditions that characterize Guam warehouses. Health concerns also clearly apply to several other chemicals that have shown some promise in inducing snake avoidance, such as chloroform, kerosene, and xylene (Nishimura 1999; T. Mathies \& W. Pitt unpublished data).

In summary, although our trials involved snakes larger on average than those typically found on Guam, four problems limit the efficacy of using essential oils (and several other investigated chemicals) to drive snakes from cargo refuges, and all except possibly the first will apply to sequestered snakes of any size: (1) vapor concentrations of these compounds are insufficient to elicit flight behavior; (2) aerosolized formulations of these compounds are of unreliable efficacy in eliciting snake repellency; (3) certain cargo goods are susceptible to chemical damage from some of these products; and (4) several of these compounds pose potential hazards to human health. These problems characterize all chemicals we tested, even those that did elicit some snake response (Table 6). Given these multiple limitations, we can only conclude that there is low probability that essential oils or their active primary compounds can be developed into reliable products for eliciting exit of snakes from cargo under operational field conditions.

Table 6. The criteria for effective operational use failed by those compounds eliciting some snake response in our trials.

\begin{tabular}{lccccc}
\hline & \multicolumn{5}{c}{ Criterion for effectiveness } \\
\cline { 2 - 6 } & Vapors elicit snake exit? & Efficacy reliable? & Residue left on goods? & Liable to damage goods? & Health hazard?* $^{*}$ \\
\hline Naphthalene & $\mathrm{N}$ & $\mathrm{N}$ & $\mathrm{N}$ & $\mathrm{N}$ & May be harmful \\
Cinnamon oil & $\mathrm{N}$ & $\mathrm{N}$ & $\mathrm{Y}$ & $\mathrm{Y}$ & May be harmful \\
Citronella oil & $\mathrm{N}$ & $\mathrm{N}$ & $\mathrm{Y}$ & $\mathrm{Y}$ & May be harmful \\
Juniper oil & $\mathrm{N}$ & $\mathrm{N}$ & $\mathrm{Y}$ & $?$ & May be irritating \\
Lavender oil & $\mathrm{N}$ & $\mathrm{N}$ & $\mathrm{Y}$ & $?$ & May be irritating \\
\hline
\end{tabular}

*Taken from National Fire Protection Association standards. 
Carbon dioxide had the potential to avoid some of these problems (1, 3, and 4 above) because it is a readily manipulable gas, is chemically unreactive with cargo products, is cheap, and low concentrations are safe for human use. However, the two snakes we tested failed to react to the gas under a wide range $(1 \%-6.3 \%)$ of concentrations safe for human use. We did not test higher concentrations because an $8 \%$ mixture is lethal to humans and, hence, could raise safety issues similar to those applicable to the use of essential oils. This failure to behaviorally react is probably because snakes are relatively resistant to the effects of $\mathrm{CO}_{2}$ and can, when they detect elevated $\mathrm{CO}_{2}$ concentrations, easily hold their breath for periods longer than the duration of these trials (Heatwole 1975; Irvine \& Prang 1976). Theoretically, one could conduct longer trials to test for $\mathrm{CO}_{2}$ repellency, but these would likely have to extend to a length of time (10-20 minutes, the length of time many snakes can readily hold their breath) that would obviate the chemical's utility under operational conditions. If the goal is to develop a relatively rapid ( $\leq 5$ minutes) treatment to elicit exit of snakes from cargo, $\mathrm{CO}_{2}$ is also unlikely to prove of use as a snake repellent.

We initiated these investigations because of the persistent but untested hope for developing a chemical fumigant to impel the exit of brown tree snakes from cargo departing Guam (Brown Tree Snake Control Committee 1996; Clark \& Shivik 2002; Engeman \& Vice 2002), hopes that are still discussed at workinggroup meetings. We wish to put to rest hopes that such an operational tool is liable to easy development. Our data - and the chemical and biological properties of the compounds themselves - suggest that such hopes are likely misdirected. Alternative methods of fumigation seem to hold greater promise. In particular, we have evidence that moderately heated streams of air can rapidly induce exit of snakes from test refuges (Kraus et al. 2014), and this is likely to prove a cheaper and easier operational tool than any chemical compound so far proposed or investigated.

\section{Acknowledgements}

This study was approved as NWRC Protocol QA-1837. We thank Tom Mathies for helpful discussions.

\section{Disclosure statement}

The authors aver no conflicts of interest in carrying out this research.

\section{Funding}

This work was supported by Department of Interior's Office for Insular Affairs.

\section{References}

Brown Tree Snake Control Committee. 1996. The brown tree snake control plan. Honolulu (HI): U.S. Fish and Wildlife Service. (Final report).
Clark L, Shivik J. 2002. Aerosolized essential oils and individual natural product compounds as brown tree snake repellents. Pest Manag Sci. 58:775-783.

Engeman RM, Vice DS. 2002. Objectives and integrated approaches for the control of brown tree snakes. Integr Pest Manag Rev. 6:59-76.

Engeman RM, Vice DS, Rodriguez DV, Gruver KS, Santos WS, Pitzler ME. 1998. Effectiveness of detector dogs for locating brown tree snakes in cargo. Pac Conserv Biol. 4:256-260.

Engeman RM, Vice DS, York D, Gruver KS. 2002. Sustained evaluation of the effectiveness of detector dogs for locating brown tree snakes in cargo outbound from Guam. Int Biodeterior Biodegrad. 49:101-106.

Fritts TH 1987. Movements of snakes via cargo in the Pacific region. 'Elepaio. 47:17-18.

Fritts TH, McCoid MJ, Gomez DM. 1999. Dispersal of snakes to extralimital islands: incidents of the brown treesnake (Boiga irregularis) dispersing to islands in ships and aircraft. In: Rodda GH, Sawai Y, Chiszar D, Tanaka H, editors. Problem snake management: Habu and brown tree snake examples. Ithaca (NY): Cornell University Press; p. 209-223.

Fritts TH, Rodda GH. 1998. The role of introduced species in the degradation of island ecosystems: a case history of Guam. Ann Rev Ecol Syst. 29:113-140.

Heatwole H. 1975. Voluntary submergence times of marine snakes. Mar Biol. 32:205-213.

Hsu W-S, Yen J-H, Wang Y-S. 2013. Formulas of components of citronella oil oil against mosquitoes (Aedes aegypti). J Environ Sci Health B. 48:1014-1019.

Irvine AB, Prange HD. 1976. Dive and breath hold metabolism of the brown water snake, Natrix taxispilota. Comp Biochem Physiol. 55A:61-67.

Ivoke N, Ogbonna PC, Ekeh F, Ezenwaji NE, Atama CI, Ejere VC, Onoja US, Eyo JE. 2013. Effects of grapefruit (Citrus paradisi MacF) (Rutaceae) peel oil against developmental stages of Aedes aegypti (Diptera: Culicidae). Southeast Asian J Trop Med Public Health. 44:970-978.

Kraus F, Stahl R, Pitt W. 2014. Thermal fumigation provides a simple and effective solution for sanitizing cargo from invasive snakes. J Pest Sci. DOI 10.1007/s10340-014-0627-x.

Linck V, da Silva AL, Figueiro M, Piato AL, Herrmann AP, Birck FD, Caramao EB, Nunes DS, Moreno PRH, Elisabetsky E. 2009. Inhaled linalool-induced sedation in mice. Phytomedicine. 16:303-307.

Nishimura M. 1999. Repellents and use of prey items for delivering toxicants for control of habu (Trimeresurus flavoviridis). In: Rodda GH, Sawai Y, Chiszar D, Tanaka H, editors. Problem snake management: Habu and brown tree snake examples. Ithaca (NY): Cornell University Press; p. 158-167.

Robertson JM. 2011. Status report: the Guam military buildup. Mil Eng. 672:73-74

Rodda GH, Savidge JA. 2007. Biology and impacts of Pacific Island invasive species. 2. Boiga irregularis, the brown tree snake (Reptilia: Colubridae). Pac Sci. 61:307-324.

Santana de MT, de Oliviera MG, Santana MF, De Sousa DP, Santana DG, Carmago EA, de Oliveira AP, da Silva Almeida JRG, Quintans-Júnior LJ. 2013. Citronellal, a monoterpene present in Java citronella oil, attenuates mechanical nociception response in mice. Pharm Biol. 51:1144-1149.

Sutoh M, Ito S, Kasuya E, Yayou K. 2013. Effects of exposure to plant derived odorants on behavior and the concentration of stress-related hormones in steers isolated under a novel environment. Anim Sci J. 84:159-164.

Taarit MB, Msaada K, Hosni K, Marzouk B. 2011. Physiological changes and essential oil composition of clary sage (Salvia sclarea L.) rosette leaves as affected by salinity. Acta Physiol Plant. 33:152-162.

Teixeira B, Marques A, Ramos C, Neng NR, Nogueria JMF, Saraiva JA, Nunes ML. 2013. Chemical composition and antibacterial and antioxidant properties of commercial essential oils. Ind Crop Prod. 43:587-595. 
Tumen I, Eller FJ, Clause CA, Teel JA. 2013. Antifungal activity of heartwood extracts from three Juniperus species. BioResources. 8:12-20.

Vice DS, Engeman RM, Hall MA, Clark CS. 2009. Working dogs: the last line of defense for preventing dispersal of brown treesnakes from Guam. In: Helton WS, editor. Canine ergonomics: the science of working dogs. Boca Raton (FL): CRC Press; p. 195-204.

Vice DS, Vice DL. 2004. Characteristics of brown treesnakes Boiga irregularis removed from Guam's transportation network. Pac Conserv Biol. 10:216-220.

Williams WC, Copeland C, Boykin E, Quell SJ, Lehman DM. 2015. Development and utilization of an ex vivo bromodeoxyuridine local lymph node assay protocol for assessing potential chemical sensitizers. J Appl Toxicol. 35(1): $29-40$.

Xing F, Hua H, Selvarag JN, Yuan Y, Zhao Y, Zhou L, Liu Y. 2014. Degradation of fumonisin B1 by cinnamon essential oil. Food Control. 38:37-40.

Yoon C, Moon S-R, Jeong J-W, Shin Y-H, Cho SR, Ahn K-S, Yang J-O, Kim G-H. 2011. Repellency of lavender oil and linalool against spot clothing wax cicada, Lycorma delicatula (Hemiptera: Fulgoridae) and their electrophysiological responses. J Asia Pac Entomol. 14:411-416.

Zheljazkov VD, Astatkie T, Jeliazkova E. 2013. Year-round variations in essential oil content and composition of male and female juniper. HortScience. 48:883-886. 